\title{
CHOICE-OF-COURT AGREEMENTS IN THE E-COMMERCE INTERNATIONAL CONTRACTS
}

by

ANABELA SUSANA DE SOUSA GONÇALVES

The choice-of-court agreements are a common practice in the e-commerce international contracts. In the European Union, the choice-of-courts agreements find their legal framework in Article 25 of Regulation No.1215/2012 of the European Parliament and of the Council, of 12 December 2012, on jurisdiction and the recognition andenforcement ofjudgments in civil and commercial matters (Brussels I bis). The purpose of this paper is to analyse the current legal framework, in the European Union, of the jurisdiction agreements in international contracts concluded in e-commerce, comparing it to the previous one, and taking into consideration the interpretative options of the European Union Court of Justice (ECJ).

\section{KEY WORDS}

Brussels I bis Regulation, Choice-of-court Agreements, E-commerce Contracts, International Contracts

\section{BRUSSELS I BIS REGULATION}

The choice-of-courts agreements in the context of international contracts find their legal framework in Regulation No. 1215/2012 of the European Parliament and of the Council, of 12 December 2012, on jurisdiction and the recognition and enforcement of judgments in civil and commercial matters (Brussels I bis). ${ }^{1}$ So, it is necessary, briefly, to determine the scope of application of this Regulation. 
The Brussels I bis Regulation is one of the most important milestones of the policy of the European Union (EU) of judicial cooperation in civil matters, ${ }^{2}$ and unifies, within the EU, the rules of jurisdiction (from Article 4 to Article 35), and the rules about recognition and enforcement of judgments and the recognition and enforcement of authentic instruments and court settlements (Article 36 and Article 60).

Brussels I bis Regulation governs civil and commercial matters, according to the provisions of Section 1, Article 1, being excluded from its scope those issues listed in Section 1 and 2 of the same legal provision, as: status and legal capacity of natural persons; rights in property arising out of a matrimonial relationship and comparable relationships; maintenance obligations, resulting from family relationship, parentage, marriage or affinity; wills and successions; bankruptcy; revenue, customs and administrative matters; the liability of the State for acts and omissions in the exercise of State authority.

The existence of international elements in the situation is required to the application of the Brussels I bis Regulation, since the Regulation does not apply to purely internal situations. ${ }^{3}$ Thus, it will be applicable to those contracts which are in contact with more than one legal system.

Regarding the spatial scope of application, the international jurisdiction rules of the Brussels I bis Regulation has its application in those situations in which the defendant has its domicile in one of the Member-States (Article 4, Section 1). Otherwise, the national jurisdiction rules of the Member-States will be applicable, except in the situations identified in Article 6, Section 1: in cases of consumer contracts (Article 18, Section 1);

\footnotetext{
It is true that there are special rules in relation to choice-of-courts agreements regarding insurance contracts (Article 15), consumers contracts (Article 21) and employment contracts (Article 23), which have in account the need to protect the weaker party of the contract. However, these special regimes are excluded from the scope of this study.

2 About the politicy of judicial cooperation in civil matters see Gonçalves, A.S.S. (2016) 'Cooperação Judiciária em Matéria Civil' in Direito da União Europeia, Elementos de Direito e Política da União, ed. Alessandra Silveira, Mariana Canotilho, Pedro Madeira Froufe, Almedina, Coimbra, pp. 339-391.

3 Condition claimed in Jenard Report and in Schlosser Report, as well as in several ECJ decisions: Jenard, P. (1999) Report on the Convention, of 27 September 1968, regarding the judiciary competence and enforcement of judgements in civil and commercial matters JO C 189, p. 8; Schlosser, P. (1990) Report on the Convention on the Association of the Kingdom of Denmark, Ireland and the United Kingdom of Great Britain and Northern Ireland to the Convention on jurisdiction and the enforcement of judgments incivil and commercial matters and to the Protocol on its interpretation by the Court of Justice JO C 189, \& 21; ECJ, Andrew Owusu v. N. B. Jackson, acting under the commercial name Villa Holidays Bal-Inn Villas, Case (2005) C-281/02, de 1.3.2005, §25, still regarding the Brussels Convention, of 27 September 1968 regarding the judiciary competence and enforcement of judgements in civil and commercial matters (Brussels Convention), among others.
} 
employments contracts (Article 21, Section 2); exclusive jurisdiction (Article 24); and choice-of-court agreements (Article 25). In the cases mentioned, there can be jurisdiction of the Member-States ' courts, regardless the place of residence of the defendant. In turn, the recognition and enforcement rules will apply to the judgments issued by the Member-States' courts included within the material scope of application of Brussels I bis, according to its Article 36. The Regulation also applies to the recognition and enforcement of authentic instruments and court settlements originated from one the Member States in other Member States within its material scope of application, according to Articles 58 and 59.

Brussels I bis Regulation is in force since 10 January 2015 (Article 81) and has repealed Regulation No. 44/2001, of 22 December 2000, on jurisdiction and the recognition and enforcement of judgments in civil and commercial matters, known as Brussels I ${ }^{4}$ (Article 80). ${ }^{5}$

The choice of jurisdiction agreement is a common practice in international contracts concluded in e-commerce, and Brussels I bis establishes in Article 25 its legal framework. The purpose of this study is to analyse that legal framework comparing it to the previous one, and taking into consideration the interpretative options of the ECJ.

\section{CHOICE-OF-COURT AGREEMENTS}

The choice-of-court agreements are regulated in Article 25 of Brussels I bis Regulation, allowing the parties, by agreement, to assign jurisdiction in legal disputes in civil and commercial matters to a court or courts of a Member-State. As in the previous drafting (Article 23 Regulation No. 44/2001), this is a expression of the principle of freedom of choice by the parties, allowing them to choose a court or courts of a Member-State to settle future disputes, or a dispute that has already taken place, having the selected court exclusive jurisdiction to decide, unless otherwise agreed by the parties (Article 23, Section 1). Therefore, in harmony

4 Regulation No. 44/2001 came into force in 1 March 2002, according to its Article 76, being determinate, in Article 66, Section 1, that the provisions in this regulation are applicable to legal proceedings instituted or to documents formally drawn up or registered as authentic instruments after its entry into force, and has superseded between MemberStates the Brussels Convention, adopting its structure and, in great part, its text (article 68).

5 About the main modifications introduced by Brussels I bis to the previous Regulation, see Gonçalves, A.S.S. (2014) A Revisão do Regulamento Bruxelas I Relativo à Competência Judiciária, ao Reconhecimento e à Execução de Decisões em Matéria Civil e Comercial' in Estudos em Comemoração dos 20 Anos da Escola de Direito da Universidade do Minho. ed. Mário Monte et al., Coimbra Editora: Coimbra, pp. 39-59. 
with the principle of freedom of choice, the selected court should settle the dispute, excluding the jurisdiction of any other court that might have jurisdiction according to the rules of the Regulation. ${ }^{6}$

However, to the validity of the choice-of-court agreement, certain requirements were established in Article 23, Section 1, to ensure legal certainty and to guarantee that the parties have given their consent. ${ }^{7}$ It was necessary that one of the parties had its domicile within the territory of a Member-State and, as a substantive condition, the object of the agreement must concern a particular legal relationship. ${ }^{8}$ As formal requirements, the agreement should have to be concluded: in writing or verbally, with written confirmation; in a form which accords with practices which the parties have established between the parties; or in a form according to the usage in international trade or commerce, of which the parties know or should know and which in such commerce or trade is widely known to, and regularly observed by parties in contracts of the same type involved in the specific trade or commerce in question. Section 2 of Article 23 determined that any communication by electronic means which could allows a durable record of the agreement was equivalent to a written contract. One of the objectives of the formal requirements of Article 23 was to ensure the existence of the agreement between the parties, which was

"[...] justified by the concern to protect the weaker party to the contract by avoiding jurisdiction clauses, incorporated in a contract by one party, going unnoticed." ${ }^{9}$

So the consensus between the parties must be clearly and precisely demonstrated in the choice of jurisdiction agreement, and the substantial and formal requirements guarantee that.

Article 25, Sections 1 and 2 of Brussels I bis Regulation, retains the same text of the previous provision of Article 23, but with one major change:

\footnotetext{
6 The importance of freedom of choice principle in jurisdiction rules results from recital 11 and is recognised by the ECJ, as becomes clear in the case Refcomp SpA $v$. Axa Corporate Solutions Assurance SA and others (2013) Case C-543/10, 7. Feruary, § 26.

7 ECJ, Trasporti Castelletti Spedizioni Internazionali SpA v. Hugo Trumpy SpA.Castelletti (1999) C-159/97, 16.March, § 34; Francesco Benincasa and Dentalkit Srl, (1997) C-269/95, 03 July, § 25; Hőszig Kft. v. Alstom Power Thermal Services (2016) Case C222/15, 07.July § 32.

8 ECJ, Profit Investment Sim SpA, in liquidation v. Stefano Ossi et. al. (2016) C-366/13, 20 April, $\S 23$; Höszig Kft. v. Alstom Power Thermal Services (2015) Case C222/15, § 33.

9 ECJ, Höszig Kft. v. Alstom Power Thermal Services, Case C222/15, § 33. See also, ECJ, Trasporti Castelletti Spedizioni Internazionali SpA v. Hugo Trumpy SpA.Castelletti, C-159/97, § 24.
} 
a jurisdiction agreement, regardless the domicile of the parties, can, now, be settled, not being needed, as in the previous drafting, that one of the parties has its domicile in a Member-State (Article 25, Section 1).

Another relevant change in the writing of Article 25, comparing to the previous draft, concerns the validity of the jurisdiction agreement, on which the ECJ had already dwell on. In the case Francesco Benincasa $v$. Dentalkit $S r l^{10}$, after defining that the objective of a jurisdiction agreement is the precise and clear designation by the parties of the court that has exclusive jurisdiction (except otherwise agreed), the ECJ considered that the judicial security, resulting form that agreement, would be impaired if one of the parties could evade to what was agreed, alleging the nullity of the entire contract in which that clause is inserted. Therefore, the validity of both must be analysed autonomously, as we are before two agreements that should be treated in an independent way. ${ }^{11}$ In the same process, ECJ decided that the nullity of the contract, where the jurisdiction agreement was inserted, should be assessed by the court stipulated for in that agreement. ${ }^{12}$ Well, it is this independence of the jurisdiction agreement, regarding the other provisions of the contract, and the prohibition of challenging the validity of that clause based, only, in the contract invalidity, that Article 25, Section 5 establishes.

Brussels I bis Regulation, also solved an issue, whose solution was not clear in the previous text, where certain questions aroused. Several authors ${ }^{13}$ questioned on what would be the law that should assess the substantial validity of the jurisdiction agreement. Article 25, Section 1 of Brussels I bis Regulation, seems to indicate that the substantial validity must be assessed according to the law of the court of the Member-State that has jurisdiction, according to the choice-of-court agreement (as it is confirmed by recital 20).

10 Process C-269/95, 20.2.1997, CJ 1997, p. I-3767.

11 Magnus, U. (2012) Prorogation of jurisdiction in Brussels I Regulation, ed. U. Magnus and P. Mankowski, Sellier European Law Publishers:Munich, pp. 500-501; Visher, F. (2004) Der Einbezug deliktischer Ansprüche in die Gerichtsstandsvereinbarung für den Vertrag in Festschrift für Erik Jayme I, ed. Heinz-Peter Mansel et al., Sellier European Law Publishers: München, p. 995.

12 Francesco Benincasa contra Dentalkit Srl (1995) C-269/95, p. I-3767.

13 V. Gaudemet-Tallon, H. (2002) Compétence et Exécution des Jugements en Europe, Règlement no. 44/2001, Conventions de Bruxelles et de Lugano. $3^{\text {rd }}$ ed., Montchrestien, L.G.D.J., Paris, pp. 93, indicating some solutions for the resolution of this problem, as the query of the law of the appointed court and the law of the excluded court, about the validity of the clause; Magnus, U. (2012) Prorogation of jurisdiction. Cit., pp. 473-474, 476-478, differentiating the several substantive questions which might arise related to the jurisdiction agreement; Stone, P. (2008) EU Private International Law, Harmonization of Laws. Edward Elgar Publishing, Cheltenham - UK: Northampton - USA, p. 168. 
What must be understood as law, for the purposes of this rule, is clarified in recital 20, as including the conflict of law rules of the legal order of the Member-State appointed court. ${ }^{14}$ It seems that this option of the Brussels I bis Regulation is in line with the autonomous treatment given to the jurisdiction agreement and with the drafting of Article 5, Section 1 of the Hague Convention, of 30 June 2005, on Choice-of-Court Agreements, achieving the compatibility between the two legislative texts. ${ }^{15}$

In what concerns the interpretation of the content of a jurisdiction clause, it is not necessary that the chosen court can be identified only by its wording. According to the ECJ

"it is sufficient that the clause state the objective factors on the basis of which the parties have agreed to choose a court or the courts to which they wish to submit disputes which have arisen or which may arise between them." 16

In addition, those factors, which have to be sufficiently accurate to allow the court seised to determine its jurisdiction, may be result of particular circumstances of the case. ${ }^{17}$

Finally, under Article 26, Section 1, it is considered to exist a tacit choiceof-court agreement, when the action is brought into the courts of a MemberState which does not have jurisdiction according to the jurisdiction rules of the Regulation, but before which a defendant enters an appearance (except if the objective of that appearance is to challenge the jurisdiction

14 Hypothesis already admitted by some doctrine, regarding the assessment of the consent declaration: see e.g. Gaudemet-Tallon, H. (2002) Les Conventions de Bruxelles et de Lugano, Cit., p. 93; Magnus, U. (2012) Prorogation of jurisdiction, Cit., pp. 477-478; Stone, P. (2008) EU Private International Law, p. 168. Cfr. About this question, in the revision of the Regulation, Beraudo, J-P. (2013) Regards sur le nouveau règlement Bruxelles I sur la compétence judiciaire, la reconnaissance et l'execution des décisions en matière civile et commerciale. Clunet, Vol. 3, p. 749; Hay, P. (2013) Notes on the European Union's Brussels-I "Recast" Regulation. The European Legal Forum, Vol. 1, p. 3; Nuyts, A. (2013) La refonte du règlement Bruxelles I. RCDIP, Vol. 1, pp. 55-57; Ratkovic, T. and Rotar, D.Z. (2013) Choice-of-Court Agreements Under the Brussels I Regulation (Recast). JPIL, Vol. 9 (2), pp. 251-259.

15 As it is referred in the proposal of the European Commission (2010) Proposal for a Regulation of the European Parliament and of the Council on jurisdiction and the recognition and enforcement of judgments in civil and commercial matters. COM 748 final, Brussels, p.10.

16 Höszig Kft. V Alstom Power Thermal Services, Case C222/15, § 43.

17 Ibid. In that case, the agreement clause did not refer expressly to the courts of a Member State, but to the courts of the capital of a Member State (Paris) and the law of that State was also chosen by the parties as law of the contract. So, the ECJ considered that this jurisdiction clause fulfilled the requirements of precision demanded by the rule. It held that jurisdiction clause referring to the courts of a city of a Member State should be interpreted has referring implicitly but necessarily to the system of jurisdiction rules of that Member State: ibid, $\S 48-49$. 
of the court or if there is exclusive jurisdiction granted to another court by virtue of Article 24).

\section{JURISDICTION AGREEMENTS IN E-COMMERCE CONTRACTS}

Having settled the formal and substantial validity requirements to which a jurisdiction agreement must obey, it is relevant, now, to look upon the choice-of-court agreements in international e-commerce contracts, since the selection of the court that has jurisdiction is a common practice in e-commerce contracts.

As previously seen, nowadays the assignment of jurisdiction to a court or courts of a Member-State can be done even if both parties do not have domicile in one Member-State (Article 25, Section 1). The substantial validity of the jurisdiction agreement shall be ascertained according to the law of the Member-State of the court that has jurisdiction, in accordance with the choice-of-court agreement (Article 25, Section 1). Regarding the formal requirements, they are settled in the subparagraphs of Article 25, Section 1 and they can be applied alternatively, as previously said. The goal of formal requirements has to do with the need to safeguard the actual existence of the consent of the parties. ${ }^{18}$

From the formal requirements needed for the conclusion a jurisdiction agreement, the one that might be more difficult to accomplish in e-commerce, is the requirement foreseen in Article 25, Section 1 (a), which demands that the parties express their consent through a writing or verbal way, with a subsequent written confirmation. ${ }^{19}$ In e-commerce contracts, the jurisdiction agreements are commonly included in general conditions of contracting, and the acceptance is done through the clickwrapping technique. The question is, under these circumstances, how to satisfy the formal validity requirement foreseen in Article 25, Section 1 (a) of Brussels I bis Regulation, not forgetting that the choice-of-court

\footnotetext{
As it has been stated by ECJ, e.g. Powell Duffryn plc and Wolfgang Petereit, Case C-214/89, 10.03.1992, § 26; Galeries Segoura SPRL v. Société Rahim (1976) Case C-25/76, 14. February, § 6.

19 Fausto Pocar has also the same opinion regarding Article 23, Section 2, of the Lugano Convention on Jurisdiction and the Enforcement of Judgments in Civil and Commercial Matters, which has the same drafting as Article 23 of the Regulation No. 44/2001: Pocar, F. (2009) Convention on jurisdiction and the recognition and enforcement of judgments in civil and commercial matters, signed in Lugano on 30 October 2007 - Explanatory report. JO C, 319, $\S 109$.
} 
agreement ascribes, unless otherwise contracted, exclusive jurisdiction to the chosen court (Article 25, Section 1).

First of all, it should be considered if a jurisdiction agreement established in general conditions referred by the contract is lawful. The ECJ has already held that such a clause is lawful if the contract signed includes an express reference to general conditions which include a jurisdiction clause. ${ }^{20}$ However, the reference should be express, so that it

"[...] can be controlled by a party applying normal diligence and [...] that the general conditions containing the jurisdiction clause was actually communicated to the other contracting party. ${ }^{\prime 21}$

Secondly, it is important to consider Section 2 of Article 25, which clarifies that written form is the one that corresponds to any communication byelectronic means which provides adurable record of the agreement. The explanation of this legal provision is found on the 2001 version of Brussels I Regulation: it is as a way to adapt the rule regarding jurisdiction agreements to e-commerce contracts. In the proposal of the European Commission, which introduces the rule, it can be read that

"[...] the need for an agreement "in writing or evidenced in writing" should not invalidate a choice-of-forum clause concluded in a form that is not written on paper but accessible on screen."22

It results from the writing of the legal provision that the electronic communication, through which the jurisdiction agreement was settled, shall allow a durable record, which can be better achieved when communications between the parties, are done through e-mail, since, in this case, the electronic communication, where the jurisdiction agreement is stated, can be stored in the mail box, in the computer, in an external hard drive or can even be printed, as a last resource, allowing a durable record.

A situation that presents further complications to analyse is the one in which the contract is concluded on-line, on a website, being

20 ECJ, Trasporti Castelletti Spedizioni Internazionali SpA v. Hugo Trumpy SpA.Castelletti, C-159/97, § 13; ECJ, Profit Investment Sim SpA, in liquidation v. Stefano Ossi et. al., C-366/13, § 26; Hőszig Kft. v. Alstom Power Thermal Services, Case C 222/15, § 39.

${ }^{21}$ Höszig Kft. v. Alstom Power Thermal Services, (2016) Case C222/15, 7 July, § 40. Cfr., ECJ, Estasis Saloti di Colzani (1976) Case 24/76, 14. December, § 12.

22 European Commission (1999) Proposal for a Council Regulation (EC) on jurisdiction and the recognition and enforcement of judgments in civil and commercial matters. Brussels, 14. 7. 1999 , p. 18. 
the jurisdiction agreement integrated in the general conditions of contracting, whose acceptance is done through a simple "click" in an acceptance message appearing on screen. In these cases, is the requirement of a communication by electronic means which provides a durable record of the agreement met? $?^{23}$

To answer this question, it is relevant to analyse ECJ decision, Jaouad El Majdoub v. CarsOnTheWeb.Deutschland $\mathrm{GmbH}^{24}$, where a contract concluded on the Internet was at stake, in which no consumers were involved and that was concluded through the click-wrapping technique. Jaouad El Majdoub acquired an electric vehicle, at a favourable price, in CarsOnTheWeb website, ${ }^{25}$ having the contract, subsequently, been cancelled by the seller because, allegedly, some damages have been detected in the vehicle at the time of its preparing to delivery. Non-accepting this unilateral behaviour of the seller, the buyer addressed himself to the German court, country where CarsOnTheWeb has its domicile, questioning the behaviour of that seller and requesting the compliance of the mentioned contract. Indeed, according to the general rules of Brussels I bis Regulation, namely its Article 4, Section 1, that court would have jurisdiction, according to the principle of the defendant's domicile. $^{26}$ Note that the Regulation defines, on an autonomous way, the domicile of legal persons in its Article 63, as being the place where they have its statutory seat, its central administration or its principal place of business. ${ }^{27}$

In turn, the seller questioned the jurisdiction of the German court, alleging that in the general conditions of the contract concluded on the Internet, and accessible on the website used by the buyer, there was an jurisdiction agreement in favour of a Belgium court. CarsOnTheWeb also plead that the co-contractor of this contract, who should have been sued, was its parent-company established in Belgium, fact known to the buyer,

${ }^{23}$ It is excluded from this hypothesis those situations in which what appears on the screen corresponds to a mere invitation to a contract (in the sense that the page clarifies the conditions in which the trader is willing to contract) and in which the user is the one accessing the website and the one that starts the negotiating process, through certain behaviours which suggest the willingness of a legal binding, proceeding the responsible for the page to the subsequent acceptance of the submission, normally by $e$-mail.

24 Case C-322/14 (2015), 21. May.

25 In this case the contract was concluded online.

26 The case was decided based on the Regulation No 44/2001, being the general rule established in Article 2, Section 1.

27 Primitive Article 60 of the Regulation No. 44/2001. 
since he had asked the Belgian parent-company the issuing of an invoice (request that was attended, with the identification of this company and its location) and the price of the vehicle was paid through a deposit in a Belgian account. ${ }^{28}$

The buyer questioned the formal validity of the jurisdiction agreement which was integrated in the general conditions of the contract, because he considered that the written form required and foreseen in the Regulation had not been complied, since the general conditions of the sell did not automatically open, nor at the moment of registration, nor at the moment of the buying operation. Instead, it was necessary to select a filed indicating "click here to visualize the general conditions of supplying and payment" in a new window.

From the case resulted also that the potential buyer would have to, expressly, accept those general conditions of the contract, by ticking in a box for that, before proceeding to a purchase. However, that behaviour did not, automatically, lead to the opening of the document which contained the general conditions of the seller, being, therefore, essential an additional click in an existing specific hyperlink.

The ECJ started by restate that the objective of the formal requirements, regarding the celebration of jurisdiction agreements, is to ensure the consensus of the parties, which happened in this case, because the buyer ticked in the existing box for that effect in the website, accepting the general conditions of the contract. ${ }^{29}$ Furthermore, it was necessary to clarify the concept communication by electronic means which provides a durable record of the agreement. The ECJ had in account that the objective of the rule would be to equate to the written form, certain electronic communications aiming

28 This information raises an important question, which was not object of assessment by the ECJ, because the jurisdiction agreement was considered valid. However, if it was not the case, it would be necessary to determine if the defendant should be CarsOnTheWeb, with its domicile in Germany, and to whom the website belonged and through which the contract was concluded, or if should be its parent-company, with its domicile in Belgium. Although this question is not included in the object of this study, if the contract was concluded with CarsOnTheWeb, as it seems resulting from the case, this one should be the defendant and, according to the general rule of Article 4 of Brussels I bis Regulation (previous Article 2, Section 1), the German court would be the competent one to assess the substantial request. It is clear that this conclusion depends on who is identified in the contract concluded, as a party in the contract, element that is not clarified in the case. However, this conclusion would arise the question of the need of an international elements in the legal relationship, as a necessary condition for the application of Brussels I bis Regulation, since the plaintiff had his residence in Germany. In the case the payment is done in an account located in Belgium, which means that, the obligation of compliance of the contract by the buyer, i,e. The payment of the price, is done in Belgium.

29 ECJ, Jaouad El Majdoub v. CarsOnTheWeb.Deutschland GmbH, Case C-322/14, § 31 . 
to simplify the conclusion of electronic contracts, assuming that the accessible information through a screen is transmitted..$^{30}$ It is possible to establish here a parallelism with Article 224, Section 1, $1^{\text {st }}$ part of the Portuguese Civil Code regarding the declaration of the will of negotiation which has a recipient: it becomes effective when the recipient acknowledges or comes into its possession, meaning that it is in condition of been known by him (Article 224, Section 3, a contrario sensu). The idea is the same, however, with the necessary adjustments to the contracting techniques by electronic means: the information which is available on a screen will be, indeed, known to the receiver or it is incondition to be known by him, if he chooses to. So, the possibility of registration ensures evidence of knowledge or the possibility of knowledge of the jurisdiction agreement, before the conclusion of the contract and the consequent acceptance of it with the conclusion of the electronic contract.

Therefore, according to ECJ

"in order for electronic communication to offer the same guarantees [as written communications], in particular as regards evidence, it is sufficient that it is "possible" to save and print the information before the conclusion of the contract." ${ }^{\prime 31}$

So, the acceptance by "clicking" technique, allows recording and printing the general conditions of the contract before its conclusion, if the parties chooses to, not being necessary, for them to automatically open, at the moment of registration on the website or at the moment of buying. ${ }^{32}$ in this particular case, the conclusion of the contract would involve a clickwrapping technique, which allowed the recording of the general conditions of the contract before its conclusion, by selecting a field that would open an access hyperlink to those conditions, being, therefore, satisfied the requirement of Article 25, Section 1(a).

Thus, to meet the condition of written validity established in Article 25, Section 1 (a), in electronic contracts, it is not necessary that an actual and permanent registration of the jurisdiction agreement occurs, but only the possibility to do a durable register of that agreement, either by printing,

${ }_{30}$ ECJ, Jaouad El Majdoub v. CarsOnTheWeb.Deutschland GmbH, Case C-322/14, § 36.

31 Ibid.

32 CJEU, Jaouad El Majdoub v. CarsOnTheWeb.Deutschland GmbH, Cit., § 39. 
either by digital recording, before the conclusion of the contract, which ensures the actual knowledge or possible knowledge of the jurisdiction agreement.

\section{CONCLUSION}

The purpose of this study was to analyse the legal framework of the jurisdiction agreement in international contracts concluded in the e-commerce. The choice of jurisdiction is a common practice in these contracts and, according to Brussels I bis Regulation, this agreement can be done, even when both parties are not domiciled in one Member-State (Article 25, Section 1).

The substantial validity of the jurisdiction agreement shall be assessed according to the law of the Member-State of the court that has jurisdiction, as stated by the jurisdiction agreement (Article 25, Section 1). On the other hand, the formal requirements are foreseen within the several subparagraphs of Article 25, Section 1, alternatively, aiming the safeguard of the actual existence of a consent between the parties. The formal requirement, which seems to be more difficult to accomplish in e-commerce, is the request that the conclusion of the agreement shall be in writing or verbally, with written confirmation [Article 25, Section 1(a)], as in electronic contracts, the jurisdiction agreements are commonly integrated in the general conditions of the contract, being that acceptance done through the click-wrapping technique.

Article 25, Section 2, which was introduced as a solution aiming the e-commerce contracts, clarifies that the written form equates to any communication byelectronic means which provides adurable register of the agreement. So, it was necessary to ascertain if in contracts concluded on-line, whose acceptance is made through a simple "click" in an acceptance message appearing on screen, the requirement for a communication by electronic means which provides adurable register of the agreement is met and if it equates to a written form. After the analysis of ECJ recent jurisprudence, in the case of Jaouad El Majdoub $v$. CarsOnTheWeb.Deutschland GmbH, it can be concluded that, for the written validity requirement established on Article 25, Section 1(a) to be met in electronic contracts, it is not necessary that an actual durable register of the jurisdiction agreement exist, but only the possibility to do a durable register of that agreement, either by printing, either by digital recording 
before the conclusion of the contract. That possibility of register ensures the actual knowledge or possibility of knowledge of the jurisdiction agreement.

\section{LIST OF REFERENCES}

[1] Beraudo, J-P. (2013) Regards sur le nouveau règlement Bruxelles I sur la compétence judiciaire, la reconnaissance et l'execution des décisions en matière civile et commerciale. Clunet, Vol. 3, pp. 741-763.

[2] European Commission (2010) Proposal for a Regulation of the European Parliament and of the Council on jurisdiction and the recognition and enforcement of judgments in civil and commercial matters. COM 748 final, Brussels, pp. 1-105.

[3] European Commission (1999) Proposal for a Council Regulation (EC) on jurisdiction and the recognition and enforcement of judgments in civil and commercial matters. Brussels, 14. 7. 1999, COM 348 final, pp. 1-17.

[4] Gaudemet-Tallon, H. (2002) Compétence et Exécution des Jugements en Europe, Règlement No. 44/2001. Conventions de Bruxelles et de Lugano, $3^{\text {rd }}$ ed., Montchrestien, L.G.D.J., Paris.

[5] Gonçalves, A.S.S. (2014) a Revisão do Regulamento Bruxelas I Relativo à Competência Judiciária, ao Reconhecimento e à Execução de Decisões em Matéria Civil e Comercial in Estudos em Comemoração dos 20 Anos da Escola de Direito da Universidade do Minho. ed. ] Mário Monte et al., Coimbra Editora: Coimbra, pp. 39-59.

[6] Gonçalves, A.S.S. (2016) Cooperação Judiciária em Matéria Civil' in Direito da União Europeia,Elementos de Direito e Política da União, ed. Alessandra Silveira, Mariana Canotilho, Pedro Madeira Froufe. Almedina: Coimbra, pp. 339-391.

[7] Hay, P. (2013) Notes on The European Union's Brussels-I "Recast" Regulation. The European Legal Forum, Vol. 1, p. 3, pp. 1-8.

[8] Jenard, P. (1999) Report on the Convention, of 27 September 1968, regarding the judiciary competence and enforcement of judgements in civil and commercial matters. JO C 189, pp. 165.

[9] Magnus, U.(2012) Prorogation of jurisdiction in Brussels I Regulation. ed. U. Magnus and P. Mankowski, Sellier European Law Publishers, Munich, pp. 436-514.

[10] Nuyts, A. (2013) La refonte du règlement Bruxelles I. RCDIP, Vol. 1, pp. 1-63.

[11] Pocar, F. (2009) Convention on jurisdiction and the recognition and enforcement of judgments in civil and commercial matters, signed in Lugano on 30 October 2007 - Explanatory report. 
JO C, 319, pp. 1-56.

[12] Ratkovic, T. and Rotar, D.Z. (2013) Choice-of-Court Agreements Under the Brussels I Regulation (Recast). JPIL, Vol. 9 (2), pp. 245-268.

[13] Schlosser, P. (1990) Report on the Convention on the Association of the Kingdom of Denmark, Ireland and the United Kingdom of Great Britain and Northern Ireland to the Convention on jurisdiction and the enforcement of judgments incivil and commercial matters and to the Protocol on its interpretation by the Court of Justice. JO C 189, pp. 1- 81.

[14] Stone, P. (2008) EU Private International Law, Harmonization of Laws. Edward Elgar Publishing, Cheltenham - UK: Northampton - USA. 